DIFUSI

Volume 1, No.1, Januari 2018

ISSN 2615-2363

\title{
ALAT PERAGA PENDIDIKAN IPA FISIKA DAN MATEMATIKA UNTUK SMP SWASTA GRATIS BERKUALITAS DENGAN SISWA EKONOMI LEMAH DI BANDUNG JAWA BARAT
}

\author{
Ratu Fenny Muldiani ${ }^{1}$, Siti Samsiyah Purwaningsih ${ }^{2}$, Sri Suratmi ${ }^{3}$ \\ Unit Pelayanan MKU Politeknik Negeri Bandung

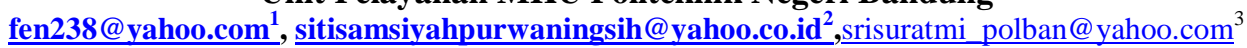

\begin{abstract}
Abstrak
Untuk lebih menarik dan mudah dalam memahami konsep Ilmu Pengetahuan Alam (IPA) Fisika dan Matematika diperlukan media pembelajaran yang lebih kongkrit. Satu media pembelajaran dari sekian banyak media yang membuat siswa tertarik terhadap IPA Fisika dan Matematika adalah dengan penggunaan alat peraga pendidikan yang sesuai dengan kebutuhan peserta didik. Alat peraga pendidikan dapat dengan mudah ditemukan dengan kualitas yang sangat baik, namun harganya tidak murah. Sekolah yang memiliki keterbatasan biaya operasional dengan siswa yang berasal dari keluarga ekonomi lemah, seperti SMP Juara Bandung mengalami kesulitan membeli alat peraga pendidikan yang harganya tinggi. SMP Juara adalah sekolah swasta gratis berkualitas terletak di kawasan Bandung Timur telah dipilih sebagai mitra 1. Pengadaan alat peraga pendidikan dalam kegiatan ini adalah pengrajin yang sudah bergelut di bidang alat peraga pendidikan, yaitu Usaha Mikro Kecil Menengah Asmed Toys di Bandung Jawa Barat. Usahanya belum berkembang karena kendala modal, kurang pemahaman konsep tentang alat-alat peraga pendidikan, tidak memperhatikan kesehatan dan keselamatan kerja (K3) serta kendala pemasaran. Selanjutnya UMKM ini disebut mitra 2. Tujuan kegiatanpengabdian Iptek bagi Masyarakat ini adalah memberikan bantuan alat peraga sebagai media pembelajaran dilengkapi dengan pelatihan penggunaan alat peraga pendidikan tersebut bagi staf pengajar IPA Fisika dan Matematika SMP mitra 1 dan satu sekolah lain dengan kondisi yang sama. Untuk mitra 2 diberikan pemahaman dan pelatihan konsep tentang pembuatan alat-alat peraga pendidikan, bimbingan teknis pembuatan alat peraga tersebut serta pemahaman tentang K3 serta strategi pemasaran. Kepada mitra 2 diberikan pula alat bantu mesin sederhana. Dampak dari kegiatan IbM ini, secara tidak langsung akan berperan serta dalam meningkatkan mutu pendidikan di kota Bandung Jawa Barat.
\end{abstract}

Kata Kunci: Alat Peraga Pendidikan, IPA Fisika dan Matematika, SMP, UMKM

\section{PENDAHULUAN}

Menurut silabus kurikulum SMP tahun 2013 secara garis besar menyebutkan bahwa Mata Pelajaran IPA Fisika pada tingkat pendidikan menengah dapat menjadi wahana bagi peserta didik untuk mempelajari diri sendiri dan alam sekitar. Proses pembelajarannya menekankan pada pemberian pengalaman langsung untuk mengembangkan kompetensi agar menjelajahi dan memahami alam sekitar secara ilmiah. Pendidikan IPA Fisika diarahkan untuk 
DIFUSI

Volume 1, No.1, Januari 2018

inkuiri dan berbuat sehingga dapat membantu peserta didik untuk memperoleh pemahaman yang lebih mendalam tentang alam sekitar.

$$
\text { Untuk Mata Pelajaran }
$$

Matematika, dalam sebuah Proceeding Pengembangan Pendidikan MIPA di Era Globalisasi menyebutkan bahwa National Council for Teacher of Mathematics (NCTM) merekomendasikan beberapa bidang keterampilan yang akan menjadi "basics" dalam pengajaran matematika, seperti: pemecahan masalah, pemakaian matematika untuk kehidupan sehari-hari, keterampilan berhitung, geometri, melek komputer dan lain sebagainya. Disebutkan pula bahwa salah satu hasil pendidikan (outcome) yang dapat mengindikasikan kapabilitas peserta didik adalah motor skills, yang diperoleh oleh peserta didik melalui pengalaman dan latihan. Keterampilan motorik diperlukan sebagai bagian penyeimbang bagi pengembangan fungsi intelektual peserta didik. Untuk meningkatkan pembelajaran MIPA tingkat dasar dan menengah dilakukan berbagai upaya dan inovasi yang dapat dikelompokan menjadi tiga, yaitu: 1) pengembangan kurikulum materi pembelajaran; 2) pengembangan fasilitas dan peralatan serta 3) peningkatan pelatihan guru.

Dalam memahami konsep Ilmu Pengetahuan Alam (IPA) Fisika dan Matematika agar lebih mudah dan menarik diperlukan media pembelajaran yang lebih kongkrit sebagai bagian dari pengembangan fasilitas dan peralatan pembelajaran. Satu media pembelajaran dari sekian banyak media yang membuat siswa tertarik terhadap IPA Fisika dan Matematika adalah dengan penggunaan alat peraga pendidikan yang sesuai dengan kebutuhan peserta didik. Manfaat dari penggunaan alat peraga adalah untuk membantu siswa menyerap materi pembelajaran secara optimal, mendalam dan utuh. Karena selain mendengarkan penjelasan materi, siswa dapat terlibat langsung melalui kegiatan melihat, menyentuh, dan mengalaminya sendiri.

Berdasarkan hasil survei (gambar 1), minimnya alat peraga pendidikan pada SMP Juara yang menjadi mitra (1) dan beberapa sekolah lain yang kondisinya sama telah menjadi salah satu kendala dalam mengoptimalkan prestasi peserta didik.

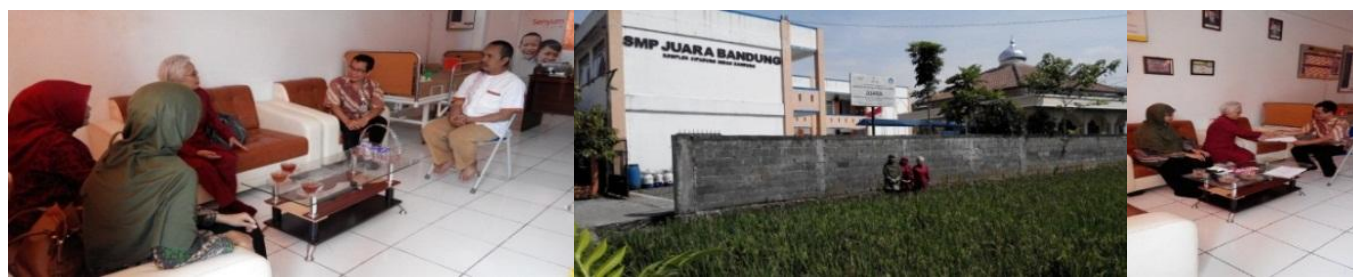

Gambar 1. Kegiatan Survey Pendahuluan Mitra (1) SMP Juara

SMP Juara Bandung berdiri pada bulan Juli 2010 di wilayah timur Bandung, yaitu di Kecamatan Panyileukan Kota Bandung. Pada awal berdiri sekolah tersebut mengontrak sebuah ruko dengan ruangan dan halaman yang sangat terbatas untuk 50 siswa yang berasal dari daerah Panyileukan dan sekitarnya. Pada Tahun 2013 sekolah berpindah ke gedung baru menempati sebidang lahan seluas 1114 meter persegi yang terletak di Komplek Taman Cipadung Indah RT 06 RW 01 Kelurahan Cipadung Kidul. Gedung dan 
tanah sekolah ini adalah wakaf dari dua orang masyarakat dan dapat menampung

Sasaran SMP Juara adalah tersekolahkannya anak-anak yatim dan miskin di sekolah gratis dan berkualitas. Sekolah yang didirikan dan dibiayai secara operasional oleh Rumah Zakat, menggunakan dana operasional yang sangat terbatas. Rumah Zakat selain membiayai SMP Juara juga membiayai beberapa program kegiatan, antara lain ambulan gratis, modal usaha keluarga
148 siswa mulai dari kelas VII sampai kelas IX.

fakir miskin, biaya transport peserta didik sekolah siswa asuhannya dan lain sebagainya. Siswa SMP Juara Bandung dengan keterbatasan ekonomi dan sarana tetap antusias meraih prestasi (gambar 3), sehingga besar harapan bila sarana belajar seperti alat peraga pendidikan dilengkapi tentunya akan semakin menambah semangat dan prestasi belajar.

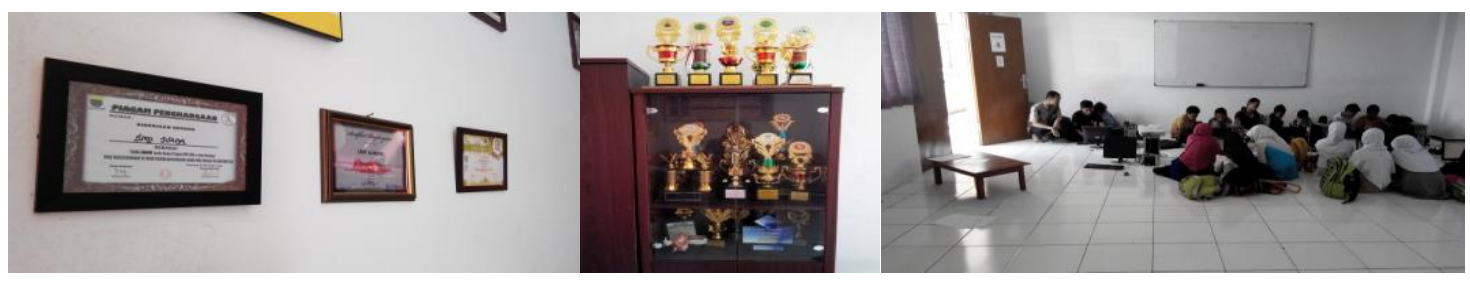

Gambar 2. Piagam/Penghargaan Prestasi dan Antusiasme Siswa saat Belajar

Sekolah dengan keterbatasan biaya operasional dan siswa yang berasal dari keluarga ekonomi lemah, seperti SMP Juara Bandung tidak mampu membeli alat peraga pendidikan yang harganya tinggi. Manajemen dan para guru bekerja keras menyiasati anggaran belanja alat peraga seminimal mungkin. Salah satu cara adalah dengan membuatnya dari barang bekas atau membeli pada home industri yang memproduksi alat peraga IPA Fisika dan Matematika dengan harga murah.

Dapat dengan mudah ditemukan produsen-produsen alat peraga pendidikan dengan kualitas yang sangat baik, namun tentunya harganya juga tidak murah. Sehingga melalui kegiatan Ipteks Bagi Masyarakat ini, menawarkan problem solving untuk mitra (1) berupa pengadaan alat peraga pendidikan melalui kemitraan dengan produsen alat peraga pendidikan sebagai mitra (2). Mitra (2) adalah masyarakat produktif secara ekonomi (usaha mikro) yang sudah bergelut di bidang alat peraga pendidikan namun masih memerlukan bantuan berupa bimbingan teknis untuk pembuatan alat peraga pendidikan. Menurut Aezaerlina (2011) alat peraga yang baik harus memenuhi beberapa kriteria, seperti kesesuaian konsep, menarik, tahan lama, multi fungsi, dan mudah.

Mitra (2) yang menjadi produsen alat peraga pendidikan yang direncanakan dalam kegiatan ini adalah Usaha Mikro Kecil Menengah (UMKM) Asmed Toys yang ada di Kota Cimahi, saat ini telah berpindah ke jalan H. Samsudin No. 52 Bandung Jawa Barat bergerak dibidang pembuatan Alat Peraga Pendidikan, seperti ditunjukkan Gambar 3. Namun usahanya belum berkembang karena kendala modal, kurangnya pemahaman konsep tentang alat-alat peraga pendidikan, dan kendala pemasaran. Beberapa alat peraga pendidikan 
DIFUSI

Volume 1, No.1, Januari 2018

diproduksi berdasarkan pesanan, dengan desain/model yang dibawa oleh pembeli

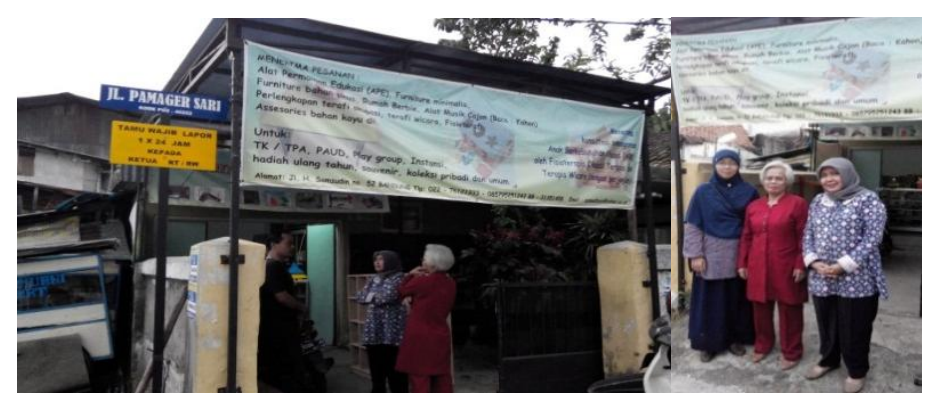

Gambar 3. Kegiatan Survey Pendahuluan Mitra (2) Asmed Toys

Alat peraga berbahan kayu dibuat dengan alat sederhana seperti Bor Duduk, Gergaji Belah, Gergaji Listrik, dan Gosokan Bin. Bahan-bahan atau alat pendukung selain kayu yang terbuat dari antara lain kaca, besi atau plastik dibuat oleh mitra Asmed Toys sesuai pesanan. Produk Asmed Toys telah menggunakan cat non toxin (tidak mengandung racun), tidak mengandung logam berat (heavy metal), seperti lead (timah), air raksa (mercury) dan bahan kimia berbahaya lainnya dikarenakan cat yang digunakan berbahan dasar air sebagai pengencernya (waterbased system) yang hanya mengeluarkan emisi pelarut organik yang sangat rendah jauh dibawah ambang batas peraturan internasional, selain juga tidak berbau dan tidak mengandung formaldehyde (bau pedas) sehingga aman bila digunakan untuk jangka pendek maupun panjang. Meskipun kualitas produk sudah sangat diperhatikan Asmed Toys masih mengabaikan keselamatan dan kesehatan kerja.

Justifikasi untuk mitra (1) adalah memberikan bantuan alat peraga sebagai media pembelajaran dilengkapi dengan pelatihan penggunaan Alat Peraga Pendidikan tersebut bagi staf pengajar IPA Fisika dan Matematika. Untuk mitra (2) memberikan pemahaman konsep tentang alat-alat peraga pendidikan, bimbingan teknis pembuatan alat peraga sesuai kebutuhan untuk materi pembelajaran IPA Fisika dan Matematika SMP, dan memberikan pemahaman dan penerapan tentang kesehatan dan keselamatan kerja (K3), dan alat bantu mesin sederhana.

Berdasarkan Analisis Situasi di atas, permasalahan pada:

- Mitra (1) adalah media pembelajaran yang tidak memadai karena terbatasnya biaya operasional terutama untuk anggaran pengadaan alat peraga pendidikan.

- Mitra (2) adalah kendala modal, minimnya alat mesin pembuat alat peraga, kurangnya pemahaman konsep tentang alat-alat peraga pendidikan, dan kendala pemasaran produk, serta pemahaman dan penerapan kesehatan dan keselamatan kerja (K3).

Solusi yang ditawarkan diuraikan sebagai berikut:

- Bagi Mitra (1) adalah memberikan bantuan alat peraga sebagai media pembelajaran beserta pelatihan penggunaannya bagi staf pengajar IPA Fisika dan Matematika. 
- Bagi Mitra (2) adalah memberikan pemahaman konsep tentang alat-alat peraga pendidikan, bimbingan teknis pembuatan alat peraga sesuai kebutuhan untuk materi pembelajaran IPA Fisika dan Matematika SMP, bimbingan tentang kesehatan dan keselamatan kerja (K3) serta pemasaran produk, dan memberikan bantuan alat bantu mesin sederhana.

\section{METODE PELAKSANAAN}

Metode secara keseluruhan yang digunakan pada pelaksanaan kegiatan pengabdian Ipteks bagi Masyarakat ini berupa observasi, diskusi, demonstrasi, simulasi, dan pelatihan. Untuk menyelesaikan masalah yang ada pada mitra (1) diberikan bantuan alat peraga sebagai media pembelajaran beserta pelatihan penggunaannya bagi staf pengajar IPA Fisika dan Matematika. Mitra (2), diberikan pemahaman konsep tentang alat-alat peraga pendidikan, bimbingan teknis pembuatan alat peraga sesuai kebutuhan untuk materi pembelajaran IPA Fisika dan Matematika SMP, bimbingan tentang kesehatan dan keselamatan kerja (K3) serta pemasaran produk, dan bantuan alat bantu mesin sederhana.

Secara teknis pelaksanaan program kegiatan pengabdian pada masyarakat ini, dapat diuraikan dengan urutan sebagai berikut.

1. Studi banding ke SMP Negeri atau swasta di Kota Bandung yang telah menggunakan Alat Peraga Pendidikan untuk pembelajaran IPA Fisika dan Matematika.

2. Survey lapangan ke beberapa SMP yang membutuhkan alat peraga pendidikan IPA Fisika dan Matematika, untuk menentukan mitra (1) dalam hal pemberian bantuan lima jenis alat peraga untuk masing-masing IPA Fisika dan Matematika.

3. Studi banding ke produsen alat peraga pendidikan yang produknya sudah digunakan dibanyak institusi sekolah dan perguruan tinggi.

4. Survey lapangan ke beberapa produsen alat peraga pendidikan di Bandung untuk menentukan mitra (2).

5. Tim pengabdian dan mitra (2) mengikuti pelatihan pembuatan dan penggunaan Alat Peraga Pendidikan IPA Fisika dan Matematika di Pudak Training Center Gedebage Bandung.

6. Memberikan bimbingan dan pelatihan kepada mitra tentang:

a. Pemahaman dan penerapan konsep pembuatan alat peraga pendidikan yang sesuai dengan kebutuhan dan pemesanan.

b. Pemahaman kesehatan dan keselamatan kerja (K3) dan pemasaran produk alat-alat peraga pendidikan.

7. Memberikan pelatihan penyusunan panduan penggunaan alat peraga bagi guru pada mitra (1) dan satu sekolah lain yang telah dipilih sebagai penerima bantuan yang sama.

8. Pengadministrasian kegiatan bantuan alat peraga pendidikan.

9. Penyusunan laporan kegiatan dan diseminasi. 


\section{HASIL YANG DICAPAI}

Berdasarkan metode dan tahapan kegiatan pelaksanaan pengabdian pada masyarakat yang telah diuraikan maka hasil yang telah dicapai adalah sebagai berikut:
1. Studi pendahuluan pada mitra (1) SMP Juara dan mitra (2) UMKM Asmed Toys, sebagai pendahuluan untuk memperoleh informasi kondisi terbaru SMP Juara dan UMKM Asmeds Toys.
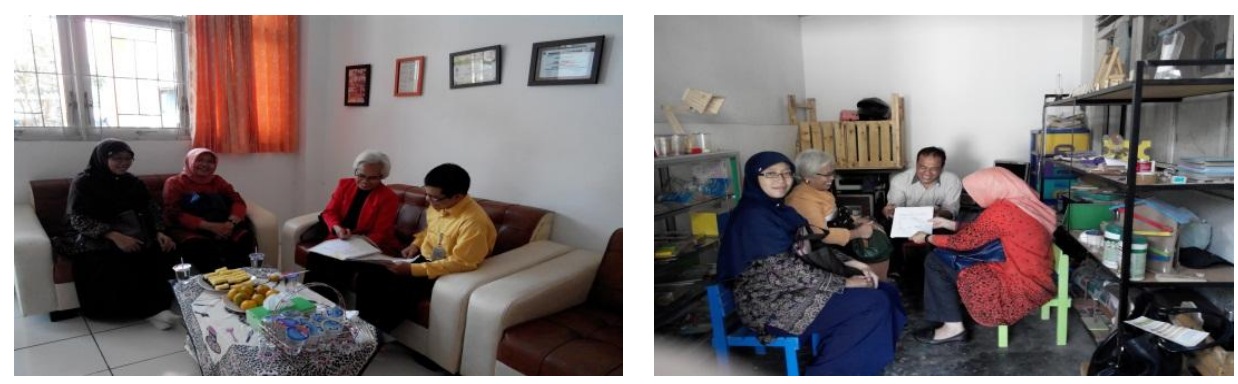

Gambar 4. Studi Pendahuluan ke SMP Juara dan UMKM Asmed Toys

Hasil yang dicapai dari kegiatan ini adalah informasi tentang SMP Juara dan UMKM Asmed Toys yang masih sesuai dengan kondisi saat survey pendahuluan mitra Sehingga, semua tahapan kegiatan dapat dilaksanakan sesuai rencana.

2. Kunjungan ke SMP Negeri yang telah menggunakan Alat Peraga Pendidikan untuk pembelajaran IPA Fisika dan Matematika. Dan ke Pudak Scientific sebagai produsen alat peraga IPA Fisika dan Matematika yang produknya telah digunakan di banyak institusi sekolah.

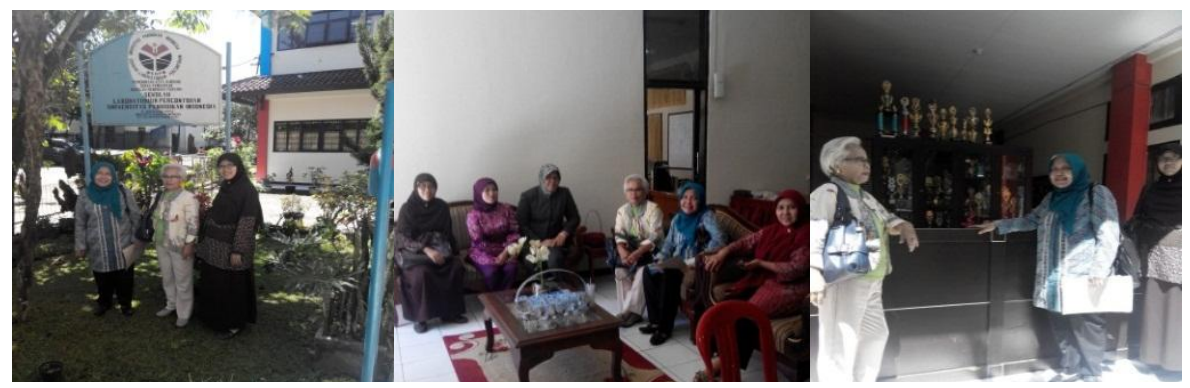

Gambar 5. Kegiatan Kunjungan ke SMP Negeri Laboratorium UPI

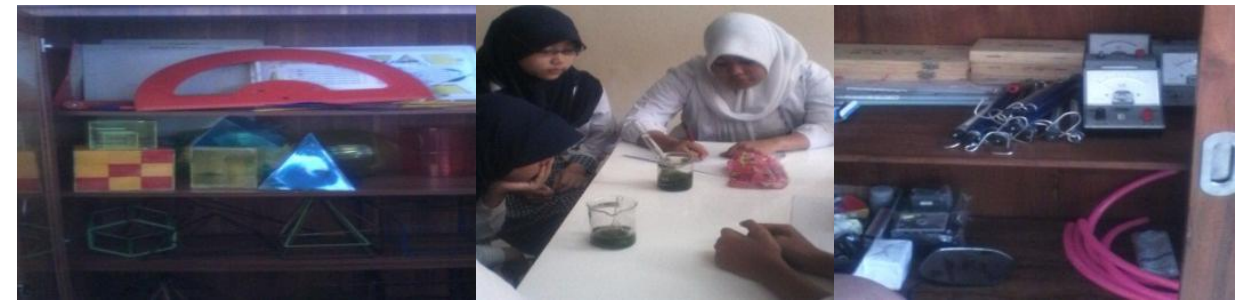

Gambar 6. Beberapa Alat Peraga dan Kegiatan Praktik di SMP Laboratorium UPI 


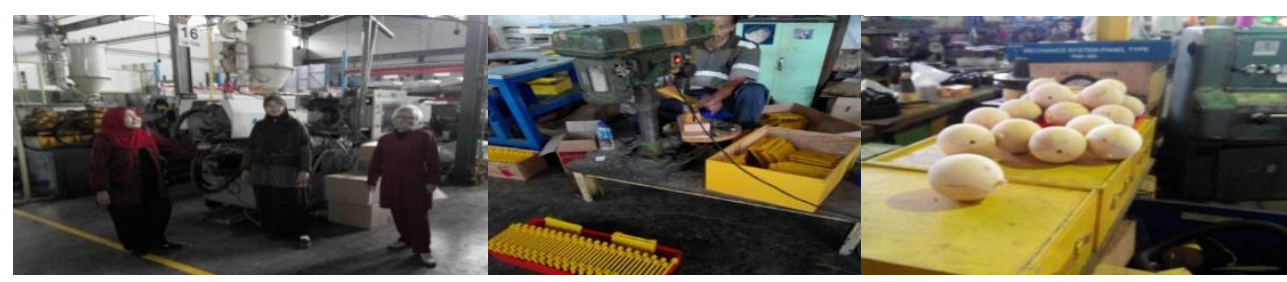

Gambar 7. Kegiatan Kunjungan ke Pudak Scientific

$\begin{array}{llr}\text { Hasil yang dicapai dari } \\ \text { kegiatan kunjungan ke } & \text { SMP } \\ \text { Laboratorium } & \text { UPI } & \text { melalui }\end{array}$
penjelasan dan diskusi dengan para pengajar IPA Fisika dan Matematika adalah informasi dan masukkan, sekaligus sebagai perbandingan bagi tim pengabdian tentang kelengkapan yang dibutuhkan dan manfaat dari penggunaan alat peraga pendidikan IPA Fisika dan Matematika dalam kegiatan belajar mengajar. Sebagai parameter bagi SMP Juara dan SMP lain penerima bantuan, yaitu SMP Mekar Rahayu dalam penyediaan alat peraga pendidikan IPA Fisika dan Matematika.
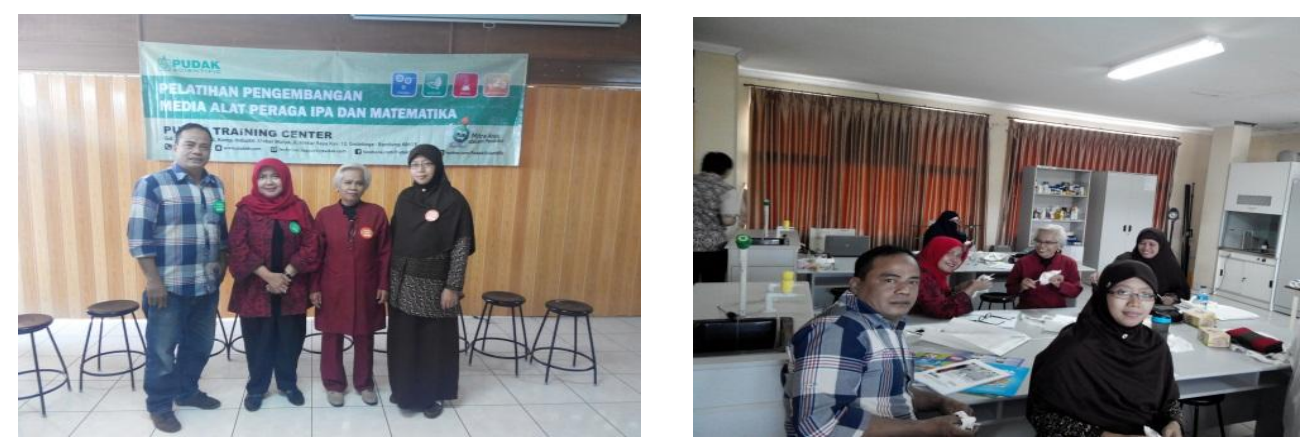

Gambar 8. Kegiatan Pelatihan Pengembangan Alat Peraga Pendidikan di Pudak Training Center Gedebage Bandung

Hasil yang dicapai dari kegiatan ini adalah Materi Pembelajaran dan Pengenalan Alat Peraga IPA dan Matematika SMP, Praktik Penggunaan dan Simulasi Alat
Hasil yang dicapai dari kunjungan ke Pudak Scientific adalah informasi bagi tim pengabdian tentang pembuatan dan pengembangan alat peraga pendidikan, memberi gambaran bagi UMKM Asmeds Toys untuk berkembang dan bersaing dalam usaha alat peraga pendidikan khususnya alat peraga pendidikan IPA Fisika dan Matematika.

3. Pelatihan bagi tim pengabdian dan mitra (2) tentang pengembangan media Alat Peraga IPA dan Matematika di Pudak Training Center Gedebage Bandung. 
tim pengabdian sebagai bahan masukan dalam memberikan pelatihan bagi guru-guru IPA Fisika dan Matematika mitra (1) SMP Juara dan SMP lain dengan kondisi yang sama. Adapun manfaat bagi mitra (2) Asmed Toys adalah pemahaman dan konsep yang mendasari pembuatan alat peraga, serta rumusan ide untuk pengembangan alat peraga apa saja yang dibutuhkan khususnya dalam pembelajaran IPA Fisika dan Matematika SMP.
4. Bimbingan teknis kepada mitra (2) UMKM Asmed Toys dalam pembuatan alat peraga pendidikan yang sesuai

dengan kebutuhan pada mitra (1) SMP Juara oleh tim pengabdian masyarakat. Bimbingan kesehatan dan keselamatan kerja (K3) disampaikan dalam bentuk pelatihan oleh narasumber yang kompeten di bidang $\mathrm{K} 3$, begitupun dengan pemberian pemahaman konsenkonsep pemasaran. UMKM Asmed Toys mendapatkan bimbingan dan arahan tentang konsep-konsep pemasaran oleh narasumber yang kompeten dibidangnya.

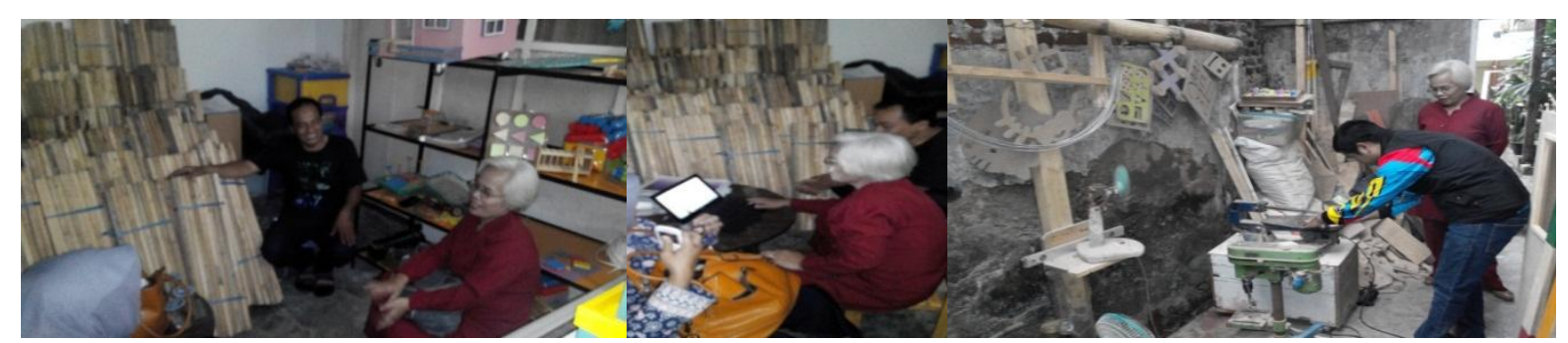

Gambar 9. Bimbingan Teknis Pembuatan Alat Peraga IPA Fisika dan Matematika SMP Serta Pelatihan Kesehatan dan Keselamatan Kerja (K3) dan Pemasaran

Hasil yang dicapai dalam kegiatan bimbingan teknis ini adalah meningkatkan produksi alat peraga pendidikan dan pemahaman konsep tentang alat-alat peraga pendidikan khususnya untuk materi pembelajaran IPA Fisika dan Matematika. Serta meningkatnya pengetahuan dan penerapan kesehatan dan keselamatan kerja
(K3) di lingkungan kerja UMKM Asmed Toys, dan peningkatan pemahaman tentang konsep-konsep pemasaran.

Untuk meningkatkan produksinya UMKM Asmed Toys diberikan bantuan alat-alat produksi seperti gergaji, sending dan bor, seperti ditunjukkan pada gambar 10 .
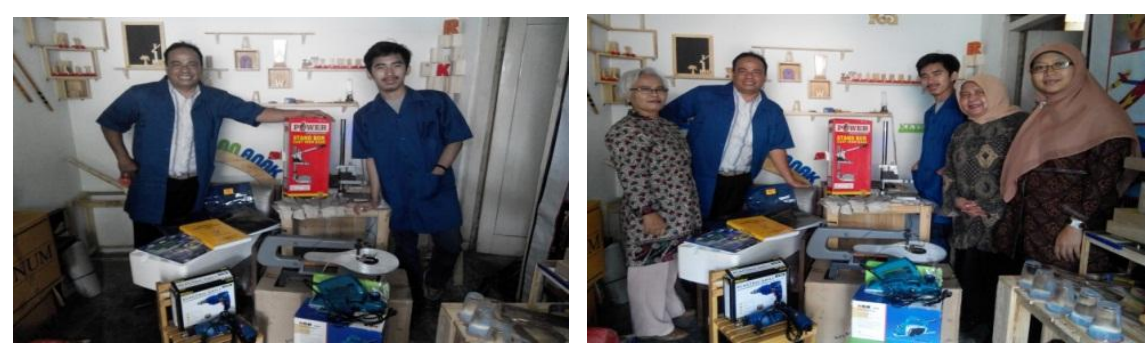

Gambar 10. Serah Terima Bantuan Alat-alat Produksi Bagi UMKM Asmed Toy 
5. Luaran kegiatan program $\mathrm{I}_{\mathrm{b}} \mathrm{M}$ berupa alat peraga pendidikan IPA Fisika dan Matematika yang diproduksi oleh UMKM Asmed Toys adalah sebagai berikut:

Tabel 1. Luaran Kegiatan (Alat Peraga Pendidikan IPA Fisika dan Matematika)

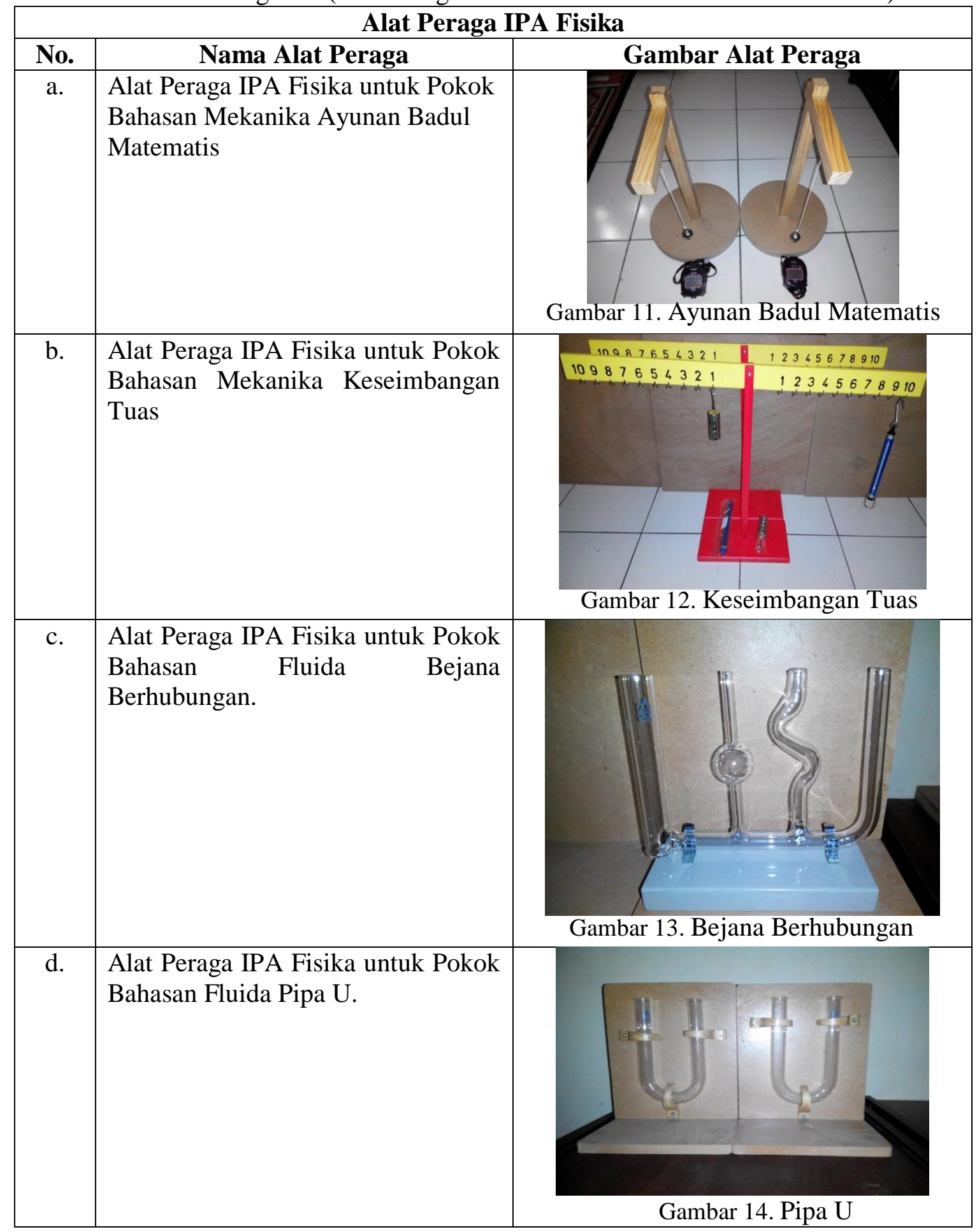




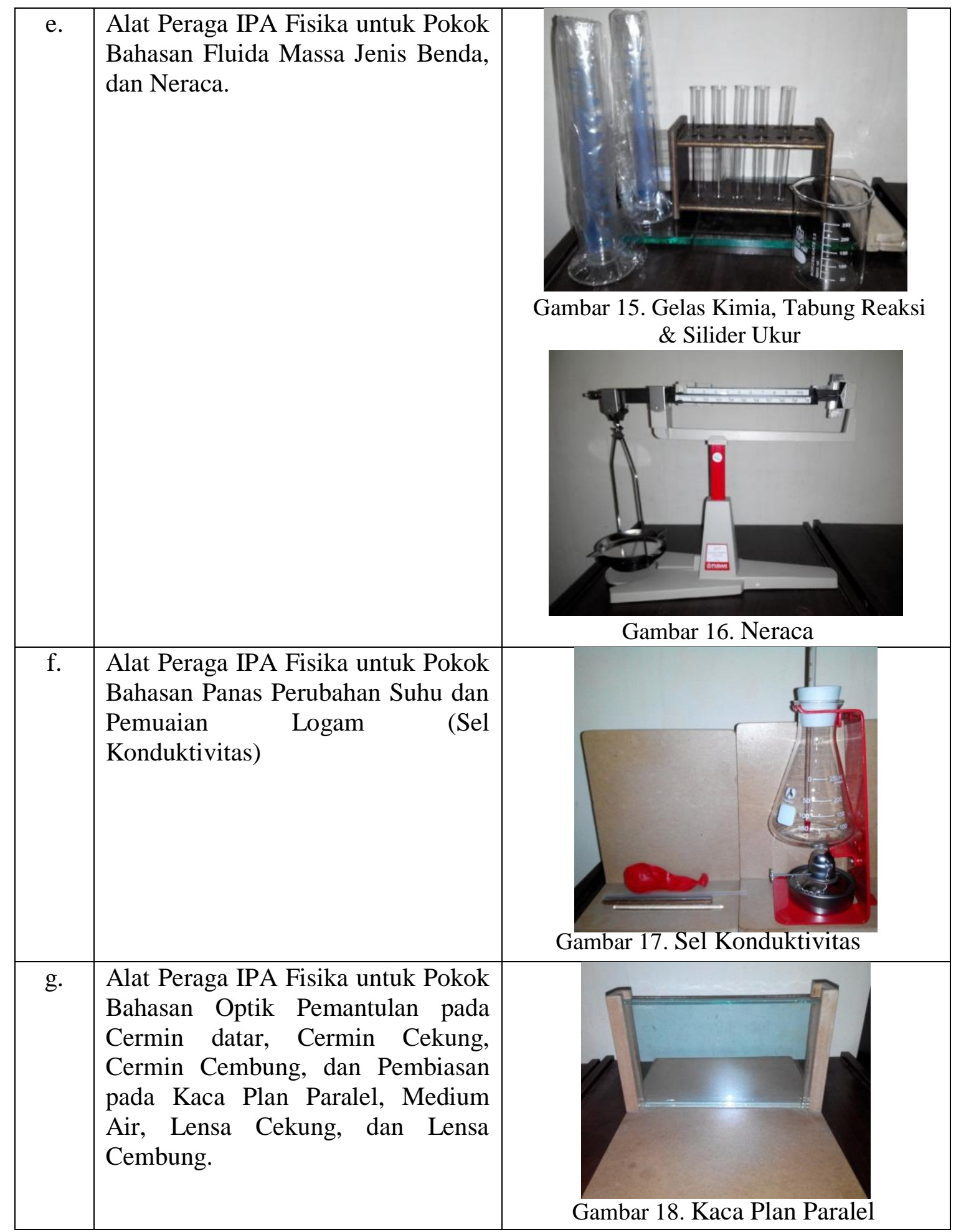


DIFUSI

Volume 1, No.1, Januari 2018

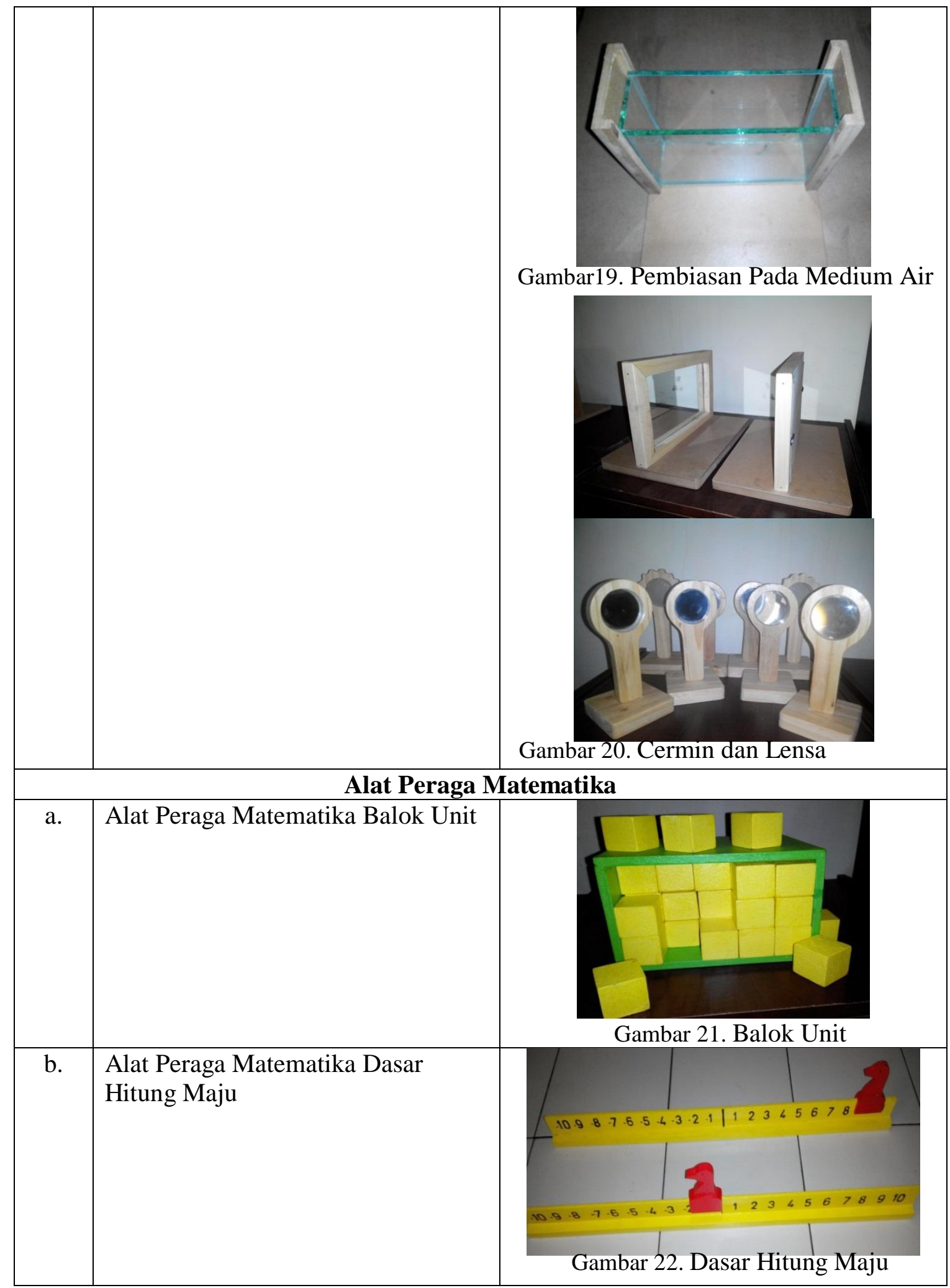


DIFUSI

Volume 1, No.1, Januari 2018

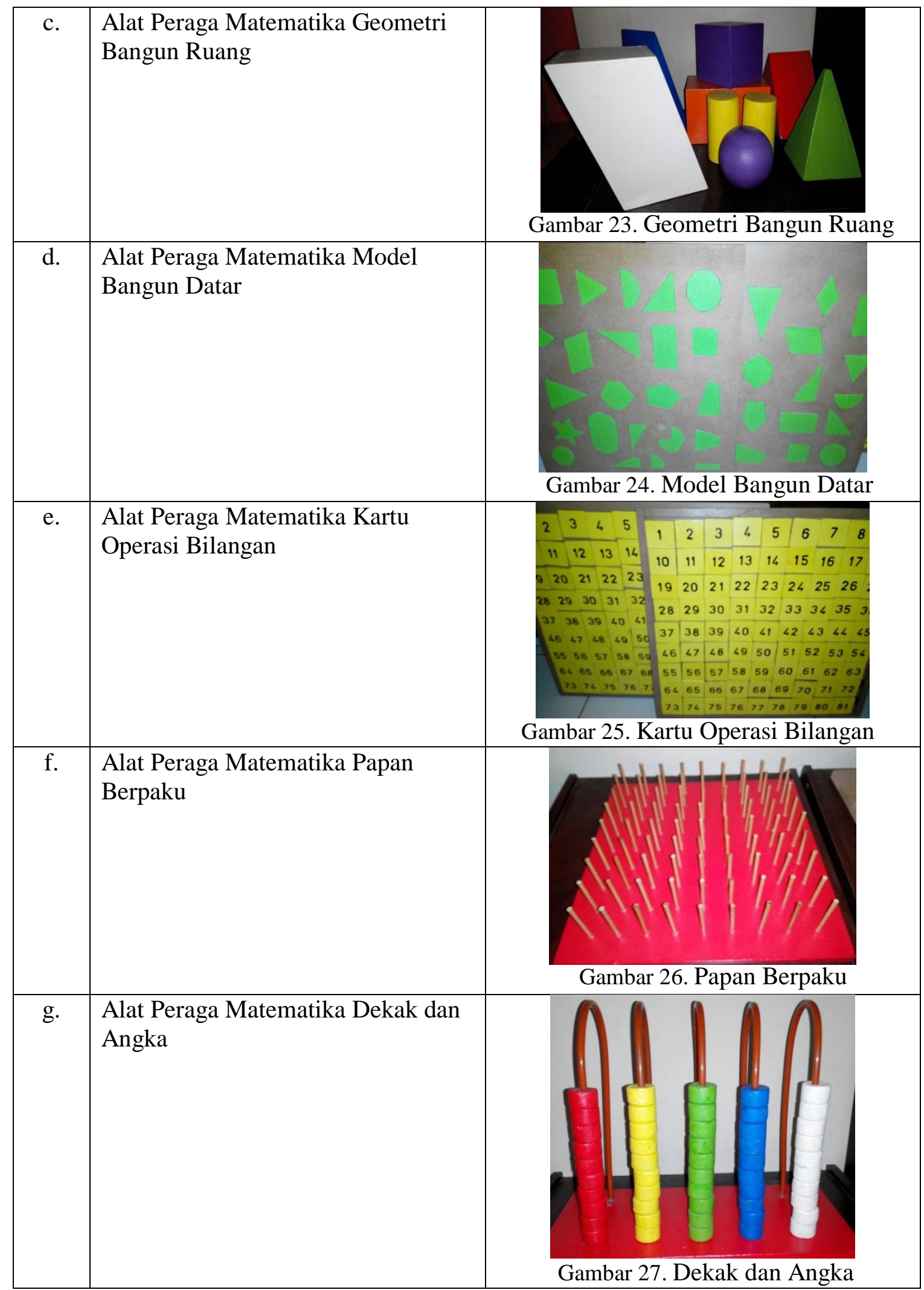




\begin{tabular}{|c|l|c|}
\hline h. & $\begin{array}{l}\text { Alat Peraga Matematika Irisan } \\
\text { Bangun }\end{array}$ \\
\hline i. & $\begin{array}{l}\text { Alat Peraga Matematika Bangun } \\
\text { Rangka }\end{array}$ & $\begin{array}{l}\text { Pangar 28. Irisan Bangun } \\
\text { j. }\end{array}$ \\
\hline $\begin{array}{l}\text { Penggaris, Segitiga Sama Sisi dan } \\
\text { Jangka }\end{array}$
\end{tabular}

6. Serah Terima Bantuan Alat Peraga Pendidikan IPA Fisika dan Matematika

Setelah pembuatan alat peraga pendidikan IPA Fisika dan Matematika oleh mitra (2) UMKM
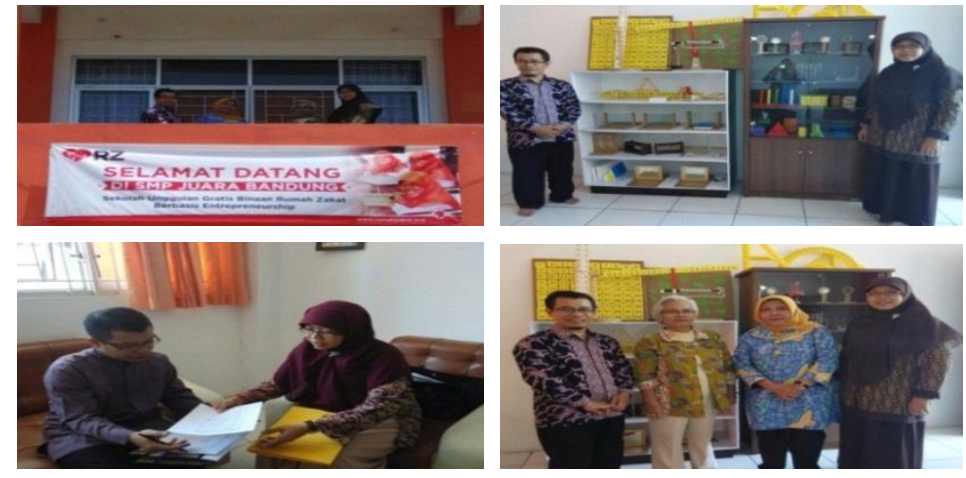

Gambar 31. Serah Terima Bantuan Alat Peraga IPA Fisika dan Matematika Kepada SMP Juara
Asmed Toys, kegiatan dilanjutkan dengan serah terima bantuan alat peraga tersebut pada mitra (1) SMP Juara dan satu SMP lain dengan kondisi yang sama, yaitu SMP Mekar Rahayu. Kegiatan tersebut dapat dilihat pada gambar 31 dan 32. 


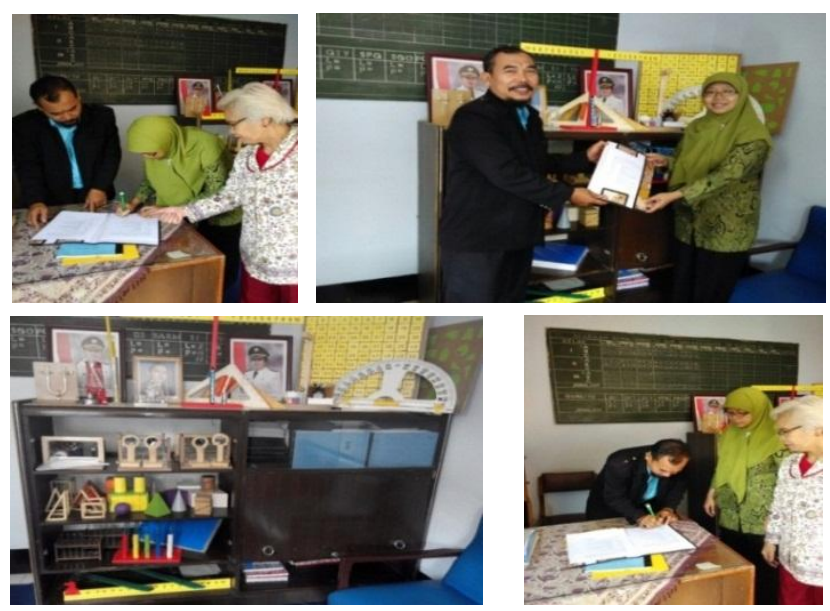

Gambar 32. Serah Terima Bantuan Alat Peraga IPA Fisika dan Matematika Kepada SMP Mekar Rahayu

7. Pelatihan penyusunan panduan penggunaan alat peraga pendidikan IPA Fisika dan Matematika.

Dalam upaya untuk mencapai target kegiatan pengabdian, yaitu meningkatkan wawasan dan keterampilan guru di SMP Juara dan SMP Mekar Rahayu dalam menggunaan alat peraga pendidikan IPA Fisika dan Matematika, kegiatan dilanjutkan dengan pelatihan penyusunan panduan penggunaan alat peraga pendidikan IPA Fisika dan Matematika. Tim pengabdian memberikan penjelasan dan bimbingan kepada guru-guru di SMP mitra tentang penggunaan alat-alat peraga pada kegiatan belajar mengajar, seperti ditunjukkan gambar 33 dan 34 . Penjelasan dan bimbingan ini kemudian dituangkan ke dalam panduan penggunaan alat peraga pendidikan IPA Fisika dan Matematika, yang selanjutnya akan digunakan dalam kegiatan belajar mengajar dalam bentuk lembar kerja siswa.

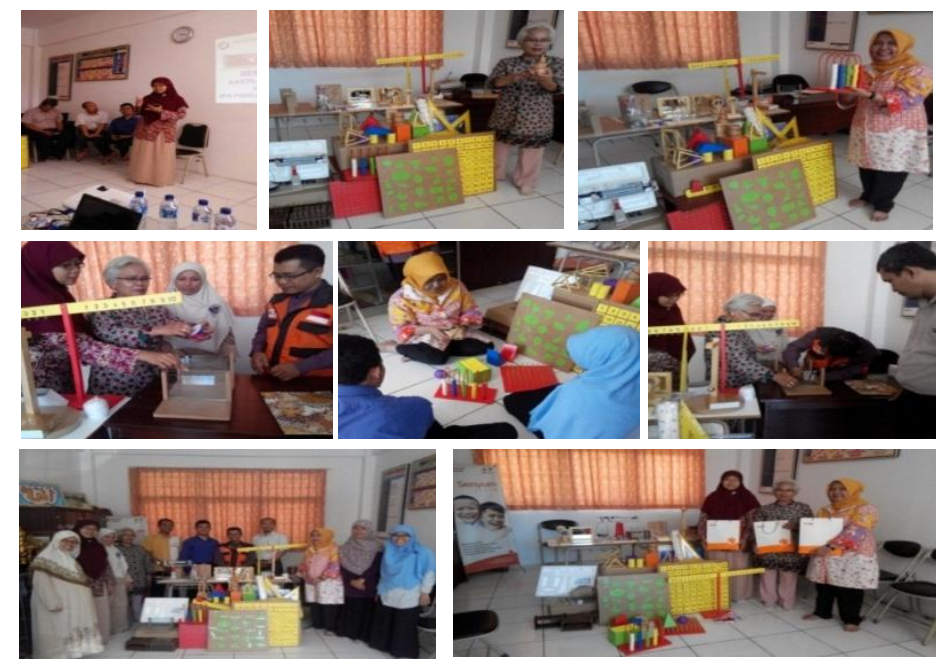

Gambar 33. Kegiatan Pelatihan di SMP Juara 

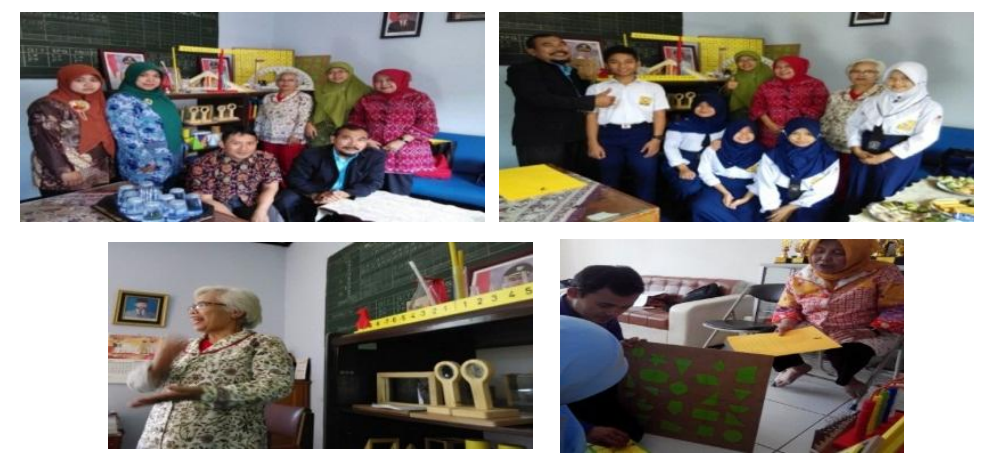

Gambar 34. Kegiatan Pelatihan di SMP Mekar Rahayu

8. Luaran dari kegiatan pelatihan berupa panduan penggunaan alat peraga dan lembar kerja siswa. Untuk pokok bahasan optik mata pelajaran IPA Fisika dan papan berpaku mata pelajaran matematika
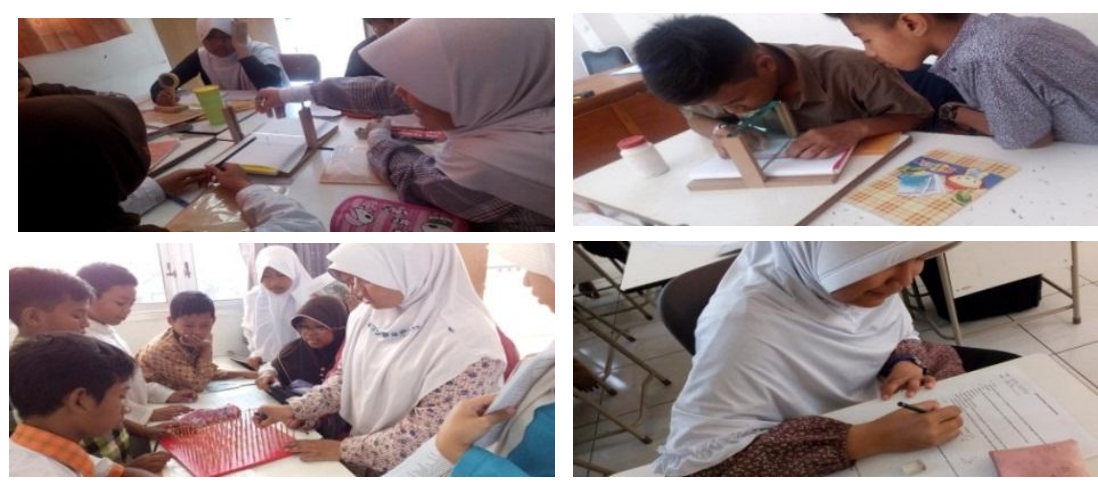

Gambar 35. Penggunaan Alat Peraga Pendidikan dalam Kegiatan Belajar di Kelas

9. Hasil belajar siswa SMP penerima bantuan alat peraga kemudian dievaluasi untuk mengetahui peningkatan motivasi belajar IPA Fisika dan Matematika.

Terdapat perbedaan yang signifikan antara nilai siswa sebelum menggunakan alat peraga dengan nilai siswa setelah menggunakan alat peraga dengan rata-rata nilai siswa sebelum menggunakan alat peragasebesar 74,56 dan rata-rata nilai siswa setelah menggunakan alat peragasebesar 85,60. Hasil evaluasi langsung dapat diaplikasikan di kelas, karena waktu yang bertepatan dengan pokok bahasan yang sedang berlangsung di kelas terlihat pada gambar 35 . 
b. Mulai melayani pesanan dari SMP dan institusi lain.

c. Meningkatnya jenis/variasi produk alat peraga pendidikan.

d. Persiapan perumusan bagi tim pengabdian dan mitra 2 untuk memperoleh HAKI atas alat peraga pendidikan produksi mitra 2.

\section{KESIMPULAN}

Kegiatan Pengabdian IbM ini telah mencapai keseluruhan kegiatan dan terlaksana secara tuntas. Telah terjadi komunikasi yang efisien dan efektif dengan kedua mitra sehingga tim pengabdian mendapatkan kelancaran dalam menjalankan tugasnya sesuai dengan rencana. Dapat diambil beberapa simpulan sebagai berikut:

1. Bimbingan teknis kepada mitra (2) UMKM Asmed Toys tentang pembuatan alat-alat peraga pendidikan IPA Fisika dan Matematika oleh tim pengabdian dapat memberikan solusi bagi mitra (2) dalam peningkatan kualitas dan kuantitas produksi khususnya alat-alat peraga IPA Fisika dan Matematika. Pelatihan K3 dan pemasaran dapat meningkatkan pengetahuan dan pemahaman pentingnya penerapan kesehatan dan keselamatan kerja (K3) di lingkungan kerja UMKM Asmed Toys, dan peningkatan pemahaman tentang konsepkonsep pemasaran.

2. Alat-alat peraga pendidikan IPA Fisika dan Matematika yang telah diproduksi mitra (2) mampu memberikan solusi bagi mitra (1) dan sekolah lain dengan kondisi yang sama, seperti SMP Mekar Rahayu dalam memenuhi kebutuhannya dalam penyediaan
Alat-alat peraga pendidikan IPA Fisika dan Matematika.

3. Luaran dari kegiatan pelatihan berupa panduan penggunaan alat peraga dan lembar kerja siswa dapat digunakan mitra (1) dalam kegiatan belajar mengajar.

4. Terdapat perbedaan yang signifikan antara nilai siswa sebelum menggunakan alat peraga dengan nilai siswa setelah menggunakan alat peraga dengan rata-rata nilai siswa sebelum menggunakan alat peragasebesar 74,56 dan rata-rata nilai siswa setelah menggunakan alat peragasebesar 85,60. Hasil evaluasi secara kualitatif, diperoleh respon positif berupa peningkatan antusiasme kegiatan belajar mengajar dari sisi pengajar maupun siswa.

5. Tetap melakukan monitoring dan pendampingan pasca kegiatan kepada mitra 2

\section{DAFTAR PUSTAKA}

Aezarlina, http://aezacan.worpress.com, diunduh18 Maret 2011.

Herawati, Susilo., 2000. Pendidikan MIPA Tingkat Dasar dan Menengah Era globalisasi di Filipina. Proceeding Seminar Nasional Pengembangan Pendidikan MIPA di Era Globalisasi. FMIPA UNY.

http://www.smpnsatap8konsel.blogspot.c om, Kurikulum 2013 Silabus Mata Pelajaran IPA dan Matematika, diunduh 10 April 2014.

http://www.rumahzakat.com, Profil SMP Juara Bandung, diunduh 4 April 2014. 
DIFUSI

Volume 1, No.1, Januari 2018

http://asmed-toys.blogspot.com, Profil UMKM Asmed Toys, diunduh 8 April 2014.

http://www.polban.ac.id, Statuta POLBAN, diunduh 17 April 2014.

Maryunis, Aleks., 2000. Srategi Peningkatan Kualitas Pendidikan MIPA LPTK, Proceeding Seminar Nasional Pengembangan Pendidikan MIPA di Era Globalisasi. FMIPA UNY.

Wahyudi, 2000. Paradigma Baru Pendidikan Sains, Proceeding Seminar Nasional Pengembangan Pendidikan MIPA di Era Globalisasi. FMIPA UNY.

, 2011, Experiments in Physics, Physics 1493/1494/2699, Columbia University, 2011 Edition, p. 5, 118-133. 